\title{
REGIONAL ANESTHESIA FOR NEUROSURGERY
}

\author{
Dinko Tonković1,2, Daniela Bandić Pavlovići, ${ }^{1,2}$, Robert Baronica ${ }^{2}$ Igor Virag $^{2}$, \\ Martina Miklić Bublić ${ }^{2}$ Nataša Kovač ${ }^{2}$ Drvar Željko \\ ${ }^{1}$ School of Medicine, University of Zagreb; \\ ${ }^{2}$ University Hospital Zagreb, Department of Anesthesiology, Reanimatology and Intensive care
}

\begin{abstract}
Summary
During neurosurgery procedures it is vital to assure optimal cerebral perfusion and oxygenation. Despite physiological autoregulation of brain perfusion, maintaining hemodynamic stability and good oxygenation during anesthesia is vital for success. General anesthesia with mechanical ventilation and current drugs provide excellent hemodynamic condition and it is the first choice for most neurosurgery procedures. However, sometimes it is very hard to avoid brief increase or decrease in blood pressure especially during period of intense pain, or without pain stimulation. This could be detrimental for patients presented with high intracranial pressure and brain edema. Modifying anesthesia depth or treatment with vasoactive drugs usually is needed to overcome such circumstances. On the other hand it is important to wake the patients quickly after anesthesia for neurological exam. That is why regional anesthesia of scalp and spine could show beneficial effects by decreasing pain stimuli and hemodynamic variability with sparing effect of anesthetics drugs. Also regional techniques provide excellent postoperative pain relief, especially after spinal surgery
\end{abstract}

Key words: neurosurgery, regional anesthesia, hemodynamic stability, postoperative analgesia

\section{Introduction}

Maintaining hemodynamic stability, good oxygenation and ventilation is crucial during neurosurgery to avoid jeopardizing cerebral perfusion $(1,2)$. For most neurosurgery procedures general anesthesia techniques with total intravenous control infusion with current drugs gets the job done successfully (1). However, during neurosurgery, pain intensity may vary because of the period of high pain stimulation during pin fixation and craniotomy and low stimulation period during intracranial pathology repair that could also provoke sudden hemodynamic instability $(2,3)$. Routine therapy for maintaining the hemodynamic stability includes different vasoactive drugs that could also impair cerebral perfusion (1). Extensive spinal surgical procedure

Correspondence to: Associate professor Dinko Tonkovic, Phd, MD, School of Medicine, University of Zagreb, University Hospital Zagreb, Department of Anesthesiology, Reanimatology and Intensive, Kišpatićeva 12,10 000 Zagreb, Croatia

E-mail: dtonkovi@mef.hrv produces high pain simulation, especially after surgery that could decrease movement and increase stress response that could then increase postoperative complication like thromboembolism or pneumonia (4). Modern neuroanesthesia with extensive neuromonitoring capabilities and safe neuroprotective anesthetic agents led to neglecting regional anesthesia in the past, but new minimal invasive surgical techniques like awake craniotomy show that there is still place for it $(3,5,6)$. Regional anesthesia, although rarely used alone, could add beneficial analgesia with minimal systemic effects on hemodynamics $(7,8,9)$ while producing additional benefits of postoperative analgesia, decreasing the dose of general anesthetics and opioids and enabling the faster awaking of patients $(2,10)$. Scalp block is an effective and standard addition to general anesthesia for craniotomy with easy performance and minimal side effects $(3,5)$. Regional anesthetic techniques for spinal surgery vary $(4,11)$. Most frequently it is performed in addition to general anesthesia for decreasing postoperative pain. Most fre- 
quently used methods are spinal anesthesia, intrathecal application of opioids and epidural catheter application for postoperative pain decrease $(11,12)$.

\section{Regional anesthesia for craniotomy}

Sensory innervation of the head relevant to neurosurgery applied to the forehead and scalp $(3,5)$. Most of the nerves supplying the scalp are superficial terminal sensory branches and lie subcutaneously so that they are easily blocked with superficial local anesthetic injection with low risk for nerve damage and systemic complications. Innervation of the forehead and anterior scalp is due to ipsilateral trigeminal nerve while posterior scalp is innervated with cranial spinal nerves $(2,3)$. For successful regional anesthesia, most commonly, bilateral nerves should be blocked. Trigeminal nerves with its branches (ophtalmicus, maxillaris and mandibularry nerves) innervate the forehead and scalp. The smallest branch, ophthalmic nerve, is a sensory nerve, carrying sensation from the ipsilateral side from upper eyelids, the cornea, ciliary body, iris, skin of the forehead, eyebrows, and the skin of the nose and through its division of the frontal nerve that goes through the superior orbital fissure ending as a supraorbital and supratrochlear nerves. These 2 branches supply sensory innervation to the forehead and anterior scalp. The maxillary nerve carries sensory sensation from face up to the zygomatic cheek prominence relevant to cheek area of the face. Mandibular nerve carries the sensation from the lower lip and the lower part of the face and the auricle and the scalp in front of and above the auricle that refers to part of the face anterior to ear. Major portion of the posterior scalp is innervated by greater occipital nerve that originates from the posterior ramus of the second cervical nerve (C2). At the back of the scalp it goes subcutaneous and inferior to the superior nuchal line, immediately medial to the occipital artery. The lesser occipital nerve originates from the ventral rami of the $\mathrm{C} 2$ and $\mathrm{C} 3$ spinal roots and is responsible for innervation of scalp skin behind the ear.

\section{Scalp block}

Local anesthetic infiltration of the scalp for craniotomies that combined local or regional anesthetics with general anesthetics was first described by Harvey
Cushing and George Crile in the early 1900s $(3,5)$. Subcutaneous infiltration of local anesthetics containing vasopressor agents has been used since the early 1900s to provide hemostasis during skin incision for craniotomy, with the first description by Braun in 1910 $(3,5)$. During the 1980, the first double-blind randomized study compared the effects of local anesthesia $0.5 \%$ bupivacaine with normal saline $(3,13,14)$. Hillman et al. found better hemodynamic stability in the bupivacaine group (3). Scalp block was first described by Girvin in 1986 for use during awake craniotomy $(3,5)$. Although neglected in neuroanesthesia practice since then, because of its beneficial hemodynamic effects, it has been reemerged for use like supplement to general anesthesia, during awake craniotomy, deep brain stimulation and stereotactic radiosurgery $(3,6)$.

\section{Technical Description}

Complete scalp block includes blocking six nerves: supraorbital, supratrochlear, auriculotemporal, zygomaticotemporal, greater and lesser occipital nerves $(3,5)$. Supraorbital and supratrochlear nerves are locked as they emerge from orbit. After palpation of supraorbital notch, for supraorbital nerve block, needle is inserted along the upper orbital margin, perpendicular to the skin, approximately $1 \mathrm{~cm}$ medial to the supraorbital foramen. Supratrochlear nerve can be blocked as it emerges above the eyebrow in the superiomedial angle of the orbit or it can be involved by a medial extension of the supraorbital block. The auriculotemporal nerve is blocked 1 to $1.5 \mathrm{~cm}$ anterior to the ear at the level of the tragus. Care must be taken to avoid puncture of the superficial temporal artery that lies anterior to the auriculotemporal nerve and should be palpated to avoid accidental puncture. Zygomaticotemporal nerve is blocked at the level of supraorbital margin, laterally to the posterior part of the zygomatic arch with deep and superficial injection. The greater occipital nerve is blocked $2.5 \mathrm{~cm}$ lateral to the nuchal median line, halfway between the occipital protuberance and the mastoid process. Care must be taken to avoid puncture of the occipital artery that lies laterally to nerve. The lesser occipital nerve is blocked $2.5 \mathrm{~cm}$ lateral to the greater occipital nerve block, by infiltration through the superior nuchal line. For anterior craniotomy suggested nerve blocks include supraorbital, supratrochelerais auriculotemporalis and zygomaticotemporalis. For poste- 
rior craniotomy suggested nerve block includes zygomaticotemporalis, greater and lesser occipital nerves. Blocks could be performed either after induction of general anesthesia or while the patients are awake. After sterile skin preparation, each block site is infiltrated with $2-5 \mathrm{ml}$ of $0.25-0.5 \%$ bupivacaine, considering maximal local anesthetic toxicity total dose. It is important to regularly aspirate before and during local anesthetic infiltration to avoid accidental intravascular injection. Depth of injection for all sites is approximately $1-1.5 \mathrm{~cm}$ superficial in skin.

\section{Regional anesthesia techniques for spinal surgery}

Another area of regional anesthesia technique, although not so extensively evaluated, but yet equally interesting, is applying regional anesthesia for spinal surgery. Spinal surgery is common and its complexity varies from minimally invasive, single-level decompression to highly complex, multi-stage extensive reconstruction (4). An anesthesiology implication for spinal surgery includes treating patients with many coexisting chronic cardiopulmonary diseases, varying in duration and magnitude of procedure and nonphysiological positioning $(4,11)$. Prone position with legs below the level of the heart for long periods could lead to relative hypovolemia and makes patients susceptible for hypotension (15). Prone positioning can result in variable effects on cardiovascular physiology. Most commonly, there is a reduction in cardiac index and reduced left ventricular compliance as a result of increased intrathoracic pressure because of gravity. Vena cava compression, because of abdominal compression, reduces venous return, produces venous stasis and increases the risk of bleeding because of increased pressure in the epidural venous plexus. It is very important to properly position the patients with pads and frames, leave the abdomen free from compression, assure normal head venous return and avoid pressure on the eyeballs. Coexisting cardiovascular and pulmonary diseases make patients even more susceptible to hemodynamic deterioration. Most common choice for spinal surgery is general anesthesia technique. Sole regional anesthesia is an option for one- or two-level lumbar laminectomy or disc surgery $(4,11)$. Attractive implementation of regional anesthesia is as a supplement to general anesthesia because of its excellent postopera- tive analgesic effect. Postoperative analgesia after spine surgery is very important because of increased risk of thromboembolism events and cardiorespiratory complications (myocardial ischemia, pneumonia) $(4,10)$. Most common scenario is the sustained stress response, inadequate analgesia, dehydration and immobility.

\section{Regional anesthesia techniques for spinal surgery}

A regional anesthesia technique for simple spinal surgery procedure includes standard spinal and epidural anesthesia, intrathecal administration of opioids and cervical plexus block $(4,11,12,16)$. Spinal anesthesia is most frequently used. Regional anesthesia in spinal surgery must be used with caution considering all standard contraindications, also taking into account the local spinal pathology and discussingthe anesthesia plan with the surgeon before procedure. Because of the potential hazard of severe hypotension during prone position and the need to convert anesthesia to general, it is wise to anticipate the difficult airway management plan beforehand. In literature there are no benefits of regional anesthesia versus general for spine surgery in terms of morbidity and mortality, however some short-term benefits of regional anesthesia have been demonstrated - for example reduction in hypertension and tachycardia, postoperative pain, postoperative nausea and vomiting, and analgesic requirement in the post anesthesia care unit $(11,12,16)$.

Beneficial effect of regional anesthesia could refer to postoperative analgesia. With standard epidural administration of opioids and local anesthetics it is also possible to administer single bolus dose of intrathecal opioids during surgery with excellent postoperative pain relief. Continuous epidural analgesia using opioid and/or local anesthetic has been shown to provide superior analgesia and reduced opioid requirement after major spine surgery, compared with intravenous patient controlled analgesia. Standard dose regimen has been used and optimal concentration, dose, and method of administration of epidural drugs have not been established (16). Epidural local anesthetic administration could compromise postoperative neurologic assessment because of motor block, so its administration should be discussed with the surgeon preoperatively and it is best avoided in certain patients who might 
need quick neurological evaluation postoperatively. Opioid of choice for intrathecal administration is morphine with a dose of $10 \mathrm{mcg} / \mathrm{kg}(12,17)$. Maximum dose for adultsof $0.4 \mathrm{mg}$ has been suggested because of the risk of opioid side effects (respiratory depression). If a higher dose is to be used (up to $1 \mathrm{mg}$ in large patients) it is imperative to assure postoperative respiratory, cardiovascular and continuous monitoring in intensive care unit.

\section{Cervical plexus block for cervical spine surgery}

Pains after cervical spine surgery could also be severe and impair patient's recovery. Regional anesthesia with cervical plexus block provide effective and safe technique as an addition to general anesthesia with better analgesia and decrease in opioid requirements, intraoperative hemodynamic stability and postoperative pain relief $(18,19)$. Although cervical plexus block could be used as a sole anesthesia technique it is rarely done because of possible long surgical procedures and uncomfortable head position. Supplementation of general anesthesia with cervical plexus block is usually done before induction to general anesthesia, while the patient is still awake. Block on $\mathrm{C} 2-\mathrm{C} 4$ nerves is required $(18,19)$. For the successful cervical plexus block it is best to use superficial or intermediate techniques $(18,19)$. Deep cervical block could have serious complications so it is best avoided. First it is important to identify the landmark as follows, posterior border of sternocleidomastoid muscle, mastoid, carotid artery and Chassaignac's tubercle of C6 vertebrae (18). Identifying posterior border of sternocleidomastoid muscle could be helped by asking the patients to lift their head while facing the other way. After finding the landmarks, it is wise to mark them with a marker. Then sterile preparation of field should be done. Injection site for both superficial and intermediate technique is at the half of the posterior border of sternocleidomastoid muscle, approximately at the level where external jugular vein crosses the muscle or at level of Chassaignac's tubercle. That is the place where nerves go out and spread to the front. Depth of the insertion is about $0.5 \mathrm{~cm}$ subcutaneous for superficial block and 1- 1.5 $\mathrm{cm}$ below platysma for intermediate block. It is important to check for accidental intravascular injection while injecting. After first site injection, operator should use fen technique along the posterior border of sternocleidomastoid muscle cranially up to mastoid level and caudally to $1 \mathrm{~cm}$ above clavicle. Typical dose of local anesthetic $(0.375-0.5 \%$ bupivacain) is up to 5 $\mathrm{ml}$ for each injection site $(18,19)$. Combining local anesthetic with $2 \mathrm{ml}$ of epinephrine, 1:200 000, enables better block with fewer systemic effects. Complications are minimal and include systemic toxicity that should be avoided by adjusting the dose and avoiding intravascular injection (20). Eventual nerve damage, if injected intraneuraly, could be avoided by not injecting in the case of resistance. Intravascular injection could be avoided by using ultrasound guided block. With normal dosing (up to $10-15 \mathrm{ml}$ of $0.375 \%$ bupivacain with epinephrine) hemodynamic consequences of local anesthetic absorption are minimal with excellent analgesia lasting up to $8-12$ hours postoperative $(18,19)$.

\section{References}

1. Ayrian E, Kaye AD, Varner CL, Guerra C, Vadivelu N, Urman $\mathrm{RD}$ et al. Effects of Anesthetic Management on Early Postoperative Recovery, Hemodynamics and Pain After Supratentorial Craniotomy. J Clin Med Res 2015;7(10):731-41.

2. Tonković D, Stambolija V, Lozić M, Martinović P, Bandić Pavlović D, Sekulić A, Perić M. Scalp block for hemodynamic stability during neurosurgery. Periodicum biologorum 2015; 117(2): 247-250.

3. Osborn I, SebeoJ. Scalp block during craniotomy: a classic technique revisited.J Neurosurg Anesthesiol 2010;22(3): 187-94.

4. De Rojas JO, Syre P, Welch WC Regional anesthesia versus general anesthesia for surgery on the lumbar spine: a review of the modern literature. Clin Neurol Neurosurg 2014;119:39-43.

5. Papangelou A, Radzik BR, Smith T, Gottschalk A. A review of scalp blockade for cranial surgery. J Clin Anesth 2013;25(2): 150-9.

6. Özlü O. Anaesthesiologist's Approach to Awake Craniotomy. Turk J Anaesthesiol Reanim 2018;46(4):250-6.

7. Geze S, Yilmaz AA, Tuzuner F. The effect of scalp block and local infiltration on the haemodynamic and stress response to skull-pin placement for craniotomy. Eur J Anaesthesiol 2009; 26(4):298-303.

8. Pinosky ML, Fishman RL, Reeves ST, Harvey SC, Patel S, Palesch Y, Dorman BH.The effect of bupivacaine skull block on the hemodynamic response to craniotomy. Anesth Analg 1996;83(6):1256-61.

9. Akhigbe T, Zolnourian A. Use of regional scalp block for pain management after craniotomy: Review of literature and critical appraisal of evidence. J Clin Neurosci. 2017 Nov;45:44-7. 
10. Šakić K, Pavić N, Tonković D, Martinac M, Bagatin D, Šakić Š. Could the choice of regional anaesthesia serve as a cost management indicator within a hospital? Periodicum biologorum 2013;115 (2):247-52.

11. Tetzlaff JE, Dilger JA, Kodsy M, et al. Spinal anesthesia for elective lumbar spine surgery. J Clin Anesth 1998;10:666-9.

12. Poblete B, Konrad C, Kothbauer KF. Intrathecal morphine analgesia after cervical and thoracic spinal cord tumor surgery. J Neurosurg Spine 2014;21(6):899-904.

13. Potters JW, Klimek M. Local anesthetics for brain tumor resection: current perspectives. Local Reg Anesth 2018;11:1-8.

14. Akcil EF, Dilmen OK, Vehid H, Ibisoglu LS, Tunali Y Which one is more effective for analgesia in infratentorial craniotomy? The scalp block or local anesthetic infiltration. Clin Neurol Neurosurg 2017;154:98-103.

15. Edgcombe H, Carter K, Yarrow S. Anaesthesia in the prone position. Br J Anaesth 2008;100:165-83.

16. Meng T, Zhong Z, Meng L. Impact of spinal anaesthesia vs. general anaesthesia on peri-operative outcome in lumbar spine surgery: a systematic review and meta-analysis of randomised, controlled trials. Anaesthesia 2017;72:391-401.

17. Araimo Morselli FS, Zuccarini F, Caporlingua F, Scarpa I, Imperiale C, Caporlingua A, De Biase L, Tordiglione P. Intrathecal versus intravenous morphine in minimally invasive posterior lumbar fusion: A blinded randomized comparative prospective study. Spine (Phila Pa 1976) 2017;42(5):281-28.

18. Tonković D, Bandić Pavlović D, Sakan S, Baronica R, Martinović Ž. Drvar Ž Drvar Ž. Intermediate cervical plexus block for carotid endarterectomy in high risk patients. Periodicum biologorum 2009;111(2): 231-4.

19. Bandić Pavlović D, Tonković D, Sakan S, Martinović Ž. The hemodynamic effect of intermediate cervical plexus block compared to general anesthesia in high risk patients with carotid endarterectomy. Periodicum biologorum 2013;115(2): 295-97.

20. Nesek Adam, V., Markić A., Šakić, K., Grizelj Stojčić E, Mršić V, Tonković D. Local anaesthetic toxicity. Periodicum biologorum 2011;113(2):141-6.

Sažetak

\section{REGIONALNA ANESTEZIJA U NEUROKIRURGIJI}

\section{Tonković, D. Bandić Pavlović, R. Baronica, I. Virag, M. Miklić Bublić, N. Kovač i Ž. Drvar}

Tijekom neurokirurših zahvata u bolesnika je vrlo bitno osigurati optimalnu cerebralnu perfuziju i oksigenaciju. Unatoč fiziološkojautoregulaciji perfuzije mozga, održavanje hemodinamske stabilnosti i dobre oksigenacije tijekom anestezije od vitalnog je značaja za uspjeh. Opća anestezija s mehaničkom ventilacijom i suvremenim anesteticima omogućuje zadovoljavajuću hemodinamsku stabilnost i prvi je izbor za većinu neurokirurških zahvata. Međutim, ponekad je vrlo teško izbjeći kratke varijacije krvnog tlaka tijekom jakih i slabih bolnih podražaja koji se izmjenjuju tijekom zahvata. Promjene sistemnog arterijskog tlaka mogu biti štetne za bolesnike s visokim intrakranijskim tlakom i edemom mozga. Liječenje se sastoji u prilagodbi dubine anestezije ili primjene vazoaktivnih lijekova. $S$ druge strane bolesnika je važno brzo probuditi nakon anestezije za neurološki pregled. Regionalna anestezija glave i kralježnice može pokazati povoljan učinak smanjenja bolnog podražaja i hemodinamske varijabilnosti uz uštedu doza anestetika. Također regionalne tehnike pružaju odličano ublažavanje postoperativne boli.

Ključne riječi: neurokirurgija, regionalna anestezija, hemodinamska stabilnost, postoperativna analgezija 